Ekonomia - Wroclaw Economic Review 26/4 (2020)

Acta Universitatis Wratislaviensis

No 4009

https://doi.org/10.19195/2658-1310.26.4.2

Beata Mucha

ORCID: 0000-0001-5103-5105

Państwowa Wyższa Szkoła Zawodowa im. A. Silesiusa

beatam3@onet.eu

Monika Mucha

ORCID: 0000-0002-8525-0345

Uniwersytet Wrocławski

mucha.monika.1987@o2.pl

\title{
Czynniki determinujące zdrowy styl życia w opinii młodych konsumentów
}

Artykuł nadesłany: 9.07.2020; artykuł zaakceptowany: 5.10.2020

Kody klasyfikacji JEL: D12, I12, L66

Keywords: young consumers, healthy lifestyle, healthy and organic food, physical activity

\begin{abstract}
Factors determining the healthy lifestyle of young consumers

The article concerns the healthy lifestyle of young consumers. The aim of the work was to determine the relationship between income and healthy lifestyle of young consumers. A healthy lifestyle is determined not only by the individual needs, but also by economic factors, which primarily include the income obtained and the price of products and services. The first part of the article presents the theoretical aspects of a healthy lifestyle. The empirical part of the publication, in turn, includes the results of one's own research. The conclusion resulting from maintaining a healthy lifestyle of young consumers is that a healthy lifestyle is to some extent determined by the amount of income.
\end{abstract}

\section{Wstęp}

Zdrowie to niekwestionowana wartość dla większości ludzi, która od lat znajduje się w centrum zainteresowania nie tylko nauk medycznych, lecz także społecznych i ekonomicznych. Badania prowadzane w latach osiemdziesiątych ubiegłego wieku w kierunku poznania determinantów zdrowia dowiodły, że jednym z czynników kształtujących i tym samym różnicujących poziom zdrowia i życia społecz- 
nego jest styl życia, traktowany jako pewna konfiguracja postaw i zachowań, wyborów i nawyków, warunkujących codzienne życie jednostki (Rogo, 2016, 230). To podejście jest szczególnie ważne w kontekście analizowania różnic pokoleniowych, gdyż transpozycja zachodząca w społeczeństwie jest efektem między innymi zmian społecznych, demograficznych, ekonomicznych i gospodarczych. Współcześni młodzi konsumenci stoją przed nowymi, nieznanymi dotąd wyzwaniami, różnicującymi ich dotychczasowy styl życia. Wielu z nich wciąż odnosi się do wzorców przekazywanych przez starsze pokolenia, jednak wzrost świadomości proekologicznej sprawia, że na pierwszy plan wysuwają się te aspekty, które nie dla wszystkich starszych osób są jasne i zrozumiałe. System wartości człowieka w dużym stopniu wpływa na jego codzienne funkcjonowanie, a zdrowa sylwetka i sprawność fizyczna stały się jednym z głównych elementów stymulujących przyjęcie proekologicznego stylu życia, zwłaszcza wśród młodych osób.

Informacje dotyczące sposobu zaspokajania potrzeb oraz preferencje konsumentów wynikające z proekologicznego stylu życia są wykorzystywane nie tylko w kontekście społecznym, ale również do pozycjonowania produktów i segmentacji rynku. Nie ulega wątpliwości, że dbałość o zdrowie jest jednym z coraz mocniej zaznaczających się megatrendów konsumenckich wykorzystywanych przez rynek żywnościowo-sportowy. Mimo że styl życia jest kwestią indywidualnego wyboru i przejawia się w konkretnej dla danej grupy postawie i zachowaniu, jest także odzwierciedleniem sposobu nabywania dóbr lub usług przez pryzmat potrzeb wynikających z przyjętego stylu życia (Sowa, 2016, 137). Zdaniem Michaela R. Solomona styl życia to

wzorzec konsumpcji odzwierciedlający to, co dana osoba lubi robić i na co wydaje pieniądze. Pojęcie to oznacza sposób rozporządzania swoimi dochodami przez konsumentów, zarówno w odniesieniu do ogólnego przeznaczania pieniędzy na różne produkty i usługi, jak i bardziej szczegółowych decyzji dotyczących wydawania ich na określone produkty w ramach określonej kategorii. (Solomon, 2006, 216)

W odniesieniu do proekologicznego stylu życia może on być w dużym stopniu warunkowany czynnikami ekonomicznymi oraz sugestywnymi reklamami, które przekonują coraz szersze grono do podejmowania określonych (w tym wypadku — prozdrowotnych) decyzji zakupowych.

Celem pracy było ustalenie czynników wpływających na prowadzenie zdrowego stylu życia w opinii młodych konsumentów. Działania prozdrowotne związane są nie tylko z poglądami i przekonaniami, które w decydujący sposób wpływają na zachowanie jednostki, lecz także z jej możliwościami finansowymi. Aby zidentyfikować te czynniki, autorki niniejszej publikacji przeprowadziły badania empiryczne na grupie reprezentatywnej. Jako podmiot badań wybrano młodych konsumentów w wieku 20-35 lat, ponieważ jest to ważna z perspektywy zrównoważonej i ekologicznej konsumpcji grupa społeczna. Uwagę skoncentrowano na dwóch aspektach: zakupie zdrowej żywności oraz korzystaniu z klubów spor- 
towych i fitness. Badania miały charakter ilościowy i wykorzystywały metodę ankietyzacji.

\section{Charakterystyka zdrowego stylu życia młodych konsumentów}

Styl życia najczęściej definiowany jest jako sposób postrzegania rzeczywistości i poruszania się $\mathrm{w}$ niej poprzez konkretne usposobienie, decyzje i interakcje społeczne. Jest również odzwierciedleniem konkretnego sytemu wartości jednostki, który wpływa na jej zachowanie (Antonides, Van Raji, 2013, 385). Z punktu widzenia nauk społecznych i ekonomicznych styl życia umożliwia jednostce spełnianie potrzeb za pomocą rozmaitych prerogatyw wynikających z miejsca w społeczeństwie i pozycji ekonomicznej (Tyszka, 1971, 19). W odpowiedzi na warunki, w jakich funkcjonuje jednostka, pojawiają się nowe koncepcje stylu życia. Jedną z nich jest zdrowy styl życia, postrzegany w kontekście jakości i warunków życia jednostki wynikających z jej prozdrowotnych postaw, związanych nie tylko z konkretnym zachowaniem, ale też z przyjętymi wartościami i zasadami zdrowego życia (Ostrowska, 1999, 150-151).

Zachowania prozdrowotne i proekologiczne mogą być kształtowane już od najmłodszych lat w wyniku socjalizacji, lecz mogą być także efektem zmian społecznych i strukturalnych. W ostatnim czasie odnotowuje się zachowania konsumenckie skierowane na zdrowy i ekologiczny styl życia będący częścią szeroko rozumianego zrównoważonego rozwoju. Przede wszystkim wybór zdrowego stylu życia wiąże się z wieloma korzyściami, między innymi dłuższym zachowaniem młodości, witalności, sprawności fizycznej, ale też zapobieganiem zachorowalności i przedwczesną śmiercią. Innym, równie ważnym, elementem warunkującym wybór zdrowego stylu życia jest świadomość ekologiczna, obejmująca

stan wiedzy, poglądów, wyobrażeń ludzi o roli środowiska w życiu człowieka, jego antropogennym obciążeniu, stopniu wyeksploatowania, zagrożenia i ochrony, w tym także stan wiedzy o sposobach i narzędziach zarządzania użytkowaniem, ochroną i kształtowaniem środowiska. (Poskrobko, 2007, 61)

Można zatem stwierdzić, że im wyższy poziom świadomości zdrowotnej i ekologicznej, tym większy jej wpływ na zachowania konsumenckie. Przekłada się to na coraz popularniejszy trend ekologizacji życia społecznego i konsumpcji, cechujący się dążeniem konsumentów do racjonalizacji zachowań konsumenckich, zwracaniem uwagi na odnawialne zasoby naturalne oraz zwiększaniem społecznej odpowiedzialności za produkcję szkodzącą środowisku (Dziewanowska, Kacprzak, 2013, 44). Odzwierciedleniem tego stanu są nie tylko postawy społeczne, lecz także działania samych producentów, którzy zmuszani są do dostosowania produkcji tak, by była przyjazna środowisku, oraz ,uwzględniania ekologicznych aspektów we wszystkich cyklach życia produktu” (Mańkowska-Wróbel, 2014, 143). 
Jednym z determinantów zdrowego stylu życia jest dochód oraz cena produktów będące dla wielu młodych konsumentów głównym czynnikiem decyzyjnym. Współczesne społeczeństwo jest świadome zalet spożywania żywności ekologicznej oraz uprawiania sportu, co uwidacznia się w wielkości zgłaszanego popytu. Wzrost świadomości konsumenckiej na ten temat sprawia, że zainteresowanie zdrową żywnością rośnie, a w miastach powstaje coraz więcej klubów fitness i siłowni (Hermaniuk, 2018, 190). Zachęcaniu młodych konsumentów do zdrowego stylu życia służą również działania marketingowe. Skuteczną formą promocji sprzedaży jest organizowanie degustacji oraz targów zdrowotnych i ekologicznych, a także zachęcanie do skorzystania z zajęć fitness lub siłowni poprzez pierwsze darmowe wejście do klubu.

Zdrowy styl życia młodych konsumentów nie jest jednak w pełni zależny od posiadanego budżetu. Zgodnie z teorią wyboru konsumenta jednostka dokonuje wyborów różnych dóbr, dążąc przy tym do osiągnięcia właściwego dla siebie poziomu zaspokojenia potrzeb i preferencji (Zalega, 2012, 156). Według tej koncepcji jednostka, wybierając zdrowy styl życia, kieruje się także poziomem uwzględnienia satysfakcji, zadowolenia i szczęścia, wynikającym z nabycia danego dobra. Dodatkowo zestawienie preferencji z możliwościami finansowanymi konsumenta pozwala przewidzieć realistyczny dobór zakupów. Preferencje są rozpatrywane jako nadawanie pierwszeństwa jednym produktom $\mathrm{w}$ stosunku do innych (Rudnicki, 2000, 320). Są także jednym z podstawowych czynników w procesie podejmowania decyzji konsumenckich, uwzględniających między innymi markę, posiadany znak jakości, certyfikacji lub innych oznaczeń na etykiecie, a także rekomendacje innych osób nabywających dane produkty lub korzystających z konkretnych usług. Współczesny młody konsument potrafi dobierać i selekcjonować produkty według własnych wymagań i upodobań (Krupa, Drobnica, 2009, 209-220).

Analiza literatury prezentującej wyniki dotychczasowych badań na temat zdrowego stylu życia pokazuje, że coraz więcej Polaków stawia na jakość kupowanych produktów żywnościowych, mimo że w ich opinii są one droższe od konwencjonalnych produktów. Według Raportu Ośrodka Ewaluacji (Leszczyńska, Pogoda, Szostakowska, Ulanicka, 2015) wysoka cena produktów ekologicznych jest dla $73 \%$ badanych największą przeszkodą. Natomiast zdaniem Kamila Chudzika badani deklarują chęć nabywania zdrowych produktów, jednak kiedy kupują produkty, w największym stopniu kierują się: ceną (75\%), a także krajem pochodzenia (65\%) czy producentem (51\%). Miejsce zakupu jest ważne dla $46 \%$ osób, a na certyfikaty zdrowej żywności i ekologicznych produktów uwagę zwraca 34\%. Zaskakująco niskie są odsetki wskazań przy takich kwestiach, jak jakość produktów, wartości odżywcze, wygląd, data ważności oraz sposób produkcji (Chudzik, 2015).

Inne badania, przeprowadzone przez agencję badawczą MANDS w 2019 roku, pokazują, że 40\% Polaków deklaruje kupowanie zdrowej i ekologicznej żywności 
przynajmniej raz w tygodniu. Głównym miejscem zakupów są sklepy spożywcze, markety i hipermarkety oraz osiedlowe targowiska. Z kolei badania CBOS z 2019 roku wskazują, że w ciągu ostatnich kilku lat wzrosła proekologiczna świadomość konsumencka, w związku z czym podwoił się odsetek respondentów wybierających zdrowy styl życia. Prawie połowa Polaków (48\%) deklaruje regularne uprawianie sportu, 47\% zaś wybiera zdrową żywność (Bożewicz, 2019, 7-9).

Zapotrzebowanie na zdrową żywność w Polsce dynamicznie rośnie, jednak na tle niektórych państw europejskich (między innymi Danii i Szwajcarii) branża ta ma jeszcze wiele barier do pokonania, wśród których najważniejszą jest brak doświadczenia, rozdrobnienie produkcji i podaży, co w konsekwencji generuje wysokie koszty wytworzenia (Moczulski, 2018).

Jeszcze do niedawna w sklepach dyskontowych i marketach trudno było spotkać się z ofertą zdrowych i ekologicznych produktów. Żywność ekologiczna była dostępna głównie w ekosklepach lub online. Obecnie jedzenie dobrej jakości, bez konserwantów i innych dodatków możliwe jest do nabycia w większości znanych marketów, jak Lidl, Biedronka, Aldi czy Kaufland. Co więcej, sklepy te oferują coraz szerszą gamę dostępnych produktów z serii „eko”, „,bio” i ,,wege/vegan”.

\section{Metodyka badania empirycznego}

Głównym celem badań było ustalenie, jakie czynniki warunkują zdrowy styl życia młodych konsumentów. Weryfikacji poddano następujące aspekty:

1. Jaki jest główny powód nabywania zdrowej żywności przez młodych konsumentów?

2. Które produkty ze zdrowej żywności są najczęściej nabywane przez młodych konsumentów?

3. Czy zdaniem badanych wielkość dochodu determinuje ich aktywność fizyczną?

4. Czy uzyskiwany przez badanych dochód pozwala im na korzystanie z klubów sportowych i fitness?

Dotychczasowy stan badań nad zależnością między budżetem młodych konsumentów a zdrowym stylem życia pozwala stwierdzić, że istnieje niewiele opracowań wskazujących, w jakim stopniu wielkość dochodów młodych konsumentów determinuje ich prozdrowotny styl życia. Wydaje się zatem, że obszar ten wymaga gruntownego poznania. Prowadzone do tej pory analizy skupiają się najczęściej wokół postaw i zachowań prozdrowotnych i ekologicznych, a osiągnięte wyniki tylko w nieznacznym stopniu odnoszą się do kwestii uzyskiwanego dochodu.

Badania ankietowe przeprowadzono w lutym 2020 roku w województwie dolnośląskim z wykorzystaniem kwestionariusza tradycyjnego na grupie 1000 osób [N = 1000] w wieku 20-35 lat. Systematyzacja kategorii wiekowych dopusz- 
cza możliwość nakładania się na siebie niektórych grup wiekowych nabywców, co wynika po prostu z braku precyzyjnej klasyfikacji kategorii konsumentów. $\mathrm{Na}$ wybór metody badań wpływ miała duża liczbowo w stosunku do wszystkich młodych osób w województwie dolnośląskim grupa badawcza w wieku 20-35 lat.

W badaniach wykorzystano analizę ekonomiczną i socjologiczną. W analizie ekonomicznej uwzględniono poziom dochodów młodych konsumentów, natomiast $\mathrm{w}$ analizie socjologicznej uwaga została skupiona na wybranych aspektach prozdrowotnego stylu życia, to jest na czynnikach skłaniających do zakupu zdrowej żywności, miejscu nabywania poszczególnych produktów ekologicznych oraz na częstotliwości korzystania z klubów sportowych i chęci prowadzenia zdrowego stylu życia.

Przy badaniu reprezentatywności uzyskanej próbki do sprawdzenia, czy uzyskane wyniki można uogólnić na wszystkie osoby w wieku 20-35 lat, wykorzystano test Kołmogorowa-Smirnowa.

Oznaczamy symbolami $G n_{1}(x)$ i $G n_{2}(x)$ dystrybuanty empiryczne odpowiednio dla pierwszej i drugiej próby. Statystyką testową jest (Hellwig, 1993):

$$
D n_{1}, n_{2}=\sup x\left[G n_{1}(x)-G n_{2}(x)\right]
$$

gdzie:

$\left[D n_{1}, n_{2}\right]$ - statystyka testowa

$\left[G n_{l}(x)\right]$ - dystrybuanta empiryczna dla pierwszej próby

$\left[\mathrm{Gn}_{2}(x)\right]$ - dystrybuanta empiryczna dla drugiej próby

W przypadku dużych liczności próbek $n_{1}$ i $n_{2}\left(n_{1}, n_{2}>20\right)$ korzysta się z tego, że asymptotyczny rozkład statystyki jest rozkładem Kołmogorowa, który jest niezależny od liczności próbek $n_{1}$ i $n_{2}$.

Niech:

$$
\lambda=\sqrt{ } n^{*} D n_{1} n_{2}, \text { gdzie } \mathrm{n}=\frac{n_{1} \times n_{2}}{n_{1}+n_{2}}
$$

wtedy zbiorem krytycznym testu jest przedział:

gdzie punkty krytyczne $\lambda(\alpha)$ odczytuje się z tablic (Blalock, 1975, 299), przy

$$
\left(\frac{\lambda(\alpha)}{\sqrt{ } n}\right)
$$

czym muszą one spełniać warunek: $Q(\lambda(\alpha))=1-\alpha$. 
Poniższe analizy będą przeprowadzane na poziomie istotności $\alpha=0,05$, dla którego warunek ten wygląda następująco: $Q(\lambda(\alpha))=0,95$, a $\alpha(\lambda)=1,36$. Ze względu na tę zmienną uzyskana $\mathrm{z}$ badania próba zostanie porównana $\mathrm{z}$ całą populacją wszystkich osób zamieszkałych w województwie dolnośląskim w wieku 20-35 lat.

\section{Wyniki badań}

Badania przeprowadzono na terenie trzech miast: Jeleniej Góry [ $\mathrm{N}=1000]$ 340; Wałbrzycha $[\mathrm{N}=1000]-310$ i Wrocławia $[\mathrm{N}=1000]-350$. We wszystkich miastach respondenci zostali dobrani techniką kwotowego doboru. Pod uwagę brano przedział wiekowy (20-35 lat) oraz deklarowany proekologiczny styl życia (co najmniej od roku).

Tabela 1. Podział respondentów według wieku i płci

\begin{tabular}{|l|c|c|c|}
\hline \multicolumn{1}{|c|}{ Wiek } & Ogółem & Mężczyźni & Kobiety \\
\hline $20-25$ & 335 & 282 & 53 \\
\hline $26-30$ & 405 & 150 & 255 \\
\hline $31-35$ & 260 & 155 & 105 \\
\hline Razem & 1000 & 587 & 413 \\
\hline
\end{tabular}

Źródło: wyniki badań własnych.

Dominującą grupą badanych były osoby w wieku 26-30 lat - 405 osób (40,5\%). Wśród nich zdecydowaną większość (25,5\%) stanowiły kobiety, podczas gdy mężczyzn było $15 \%$ próby. Drugą najliczniejszą grupą były osoby w wieku 20-25 lat - 335 osób $(33,5 \%)$. W tej grupie przeważali mężczyźni (68\%), przy $5,3 \%$ kobiet. W najmniej licznej grupie w wieku 31-35 lat znajdowało się 260 osób (26\%), z czego 15,5\% stanowili mężczyźni, a 10,5\% kobiety.

\section{Reprezentatywność próbki ze względu na kryterium wieku}

Testem Kołmogorowa-Smirnowa (K-S) na poziomie istotności $\alpha=0,05$ weryfikowana jest hipoteza $\mathrm{H}$, że rozkłady ankietowanych osób w wieku 20-35 lat i wszystkich osób w tym przedziale wiekowym na Dolnym Śląsku są identyczne wobec hipotezy alternatywnej $\mathrm{H}^{\circ}$, że rozkłady te różnią się istotnie między sobą. Niezbędne obliczenia zawiera tabela 2. 
Tabela 2. Obliczenia statystyki testowej testu Kołmogorowa-Smirnowa

\begin{tabular}{|c|c|c|c|c|c|c|c|c|}
\hline \multirow{2}{*}{\multicolumn{2}{|c|}{ 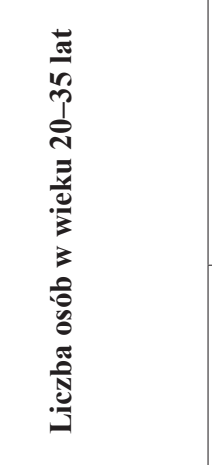 }} & \multicolumn{2}{|c|}{ 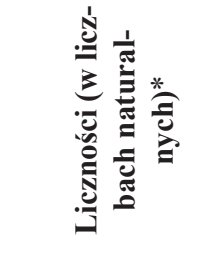 } & \multicolumn{2}{|c|}{ 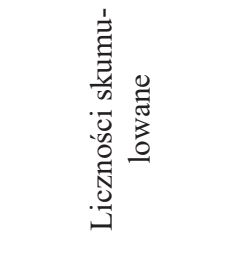 } & \multirow[t]{2}{*}{ 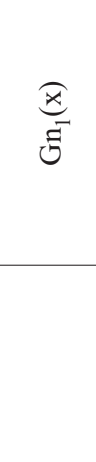 } & \multirow[t]{2}{*}{ 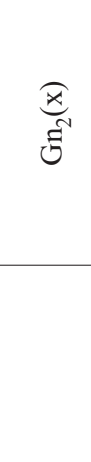 } & \multirow[t]{2}{*}{ 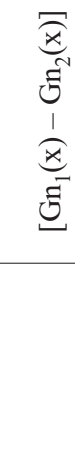 } \\
\hline & & 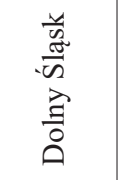 & 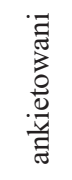 & 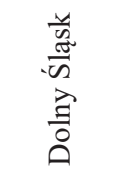 & 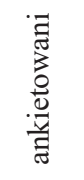 & & & \\
\hline $20-25$ & & 141819 & 335 & 141819 & 335 & 0,335 & 0,254 & 0,081 \\
\hline $26-30$ & & 179655 & 405 & 321474 & 740 & 0,740 & 0,588 & 0,152 \\
\hline $31-35$ & & 225124 & 260 & 546598 & 1000 & 1 & 1 & 0,000 \\
\hline$\Sigma$ & 546598 & 1000 & & & & & & \\
\hline
\end{tabular}

* stan na dzień 31 grudnia 2018 roku (GUS, 2019, 137)

Źródło: opracowanie własne na podstawie wyników badań.

$$
\begin{aligned}
& \qquad\left[\begin{array}{l}
\sqrt{546598 \cdot 1000} \\
546598+1000
\end{array}\right] \sqrt{10} \quad[n=3,2] \quad\left(\frac{1,36}{3,2}\right) \\
& \text { Zbiór krytyczny }\left(\frac{\lambda(\alpha)}{\sqrt{ } n}\right) ; 1 \Rightarrow 0,425
\end{aligned}
$$

Na podstawie obliczeń zawartych w tabeli 1 wiemy, że wartość statystyki testowej wynosi 0,152, a więc znajduje się ona w przedziale krytycznym, co prezentuje rysunek 1 .

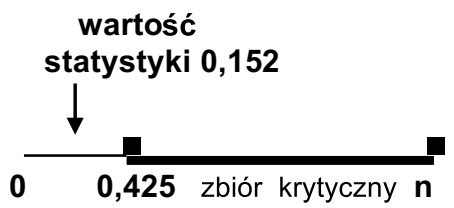

Rysunek 1. Wartość statystyki testowej K-S

Źródło: opracowanie własne na podstawie wyników badań.

Nie ma więc podstaw do odrzucenia hipotezy $\mathrm{H}$, czyli rozkłady wieku dla obu próbek można uznać za identyczne. Na tej podstawie można przyjąć, że prze- 
prowadzone badania są reprezentatywne i można je uogólnić na całą populację młodych osób w wieku 20-35 lat w województwie dolnośląskim.

\section{Analiza ekonomiczna}

W celu zweryfikowania postawionego celu konieczne było ustalenie, w jakim stopniu uzyskiwany przez młodych konsumentów dochód warunkuje prowadzenie zdrowego stylu życia. Odpowiedź na to pytanie jest ważna z wielu powodów. Otóż, jak wspomniano wcześniej, młodzi konsumenci to osoby w wieku 20-35, które mogą uzyskiwać dochód w różny sposób. Można także przypuszczać, że zarówno wielkość i źródło dochodu, jak i segment młodych konsumentów może być uwzględniany przez producentów zdrowych i ekologicznych produktów. Część z nich pracuje, część jest na utrzymaniu rodziców. Niektórzy mogą utrzymywać się z otrzymywanych świadczeń (na przykład renty, stypendium czy zasiłku). Dochód w przedziale $0-500 \mathrm{zł}$ posiada tylko $8 \%$ badanych.

W przeprowadzonych badaniach $20 \%$ osób zadeklarowało, że nie pracuje, a 5\% jest na utrzymaniu rodziców lub otrzymuje stypendium. Następnie ankietowani wskazali, jaki jest miesięczny dochód na członka ich rodziny. Najwięcej ankietowanych (36\%) podało dochód w przedziale $1001-2500$ zł na jednego członka rodziny; 25\% respondentów deklaruje dochód w granicy 2501-3000 zł na członka rodziny; najmniej osób (14\%) wskazało na dochód w przedziale 30014000 zł. Wyniki przedstawia wykres 1.

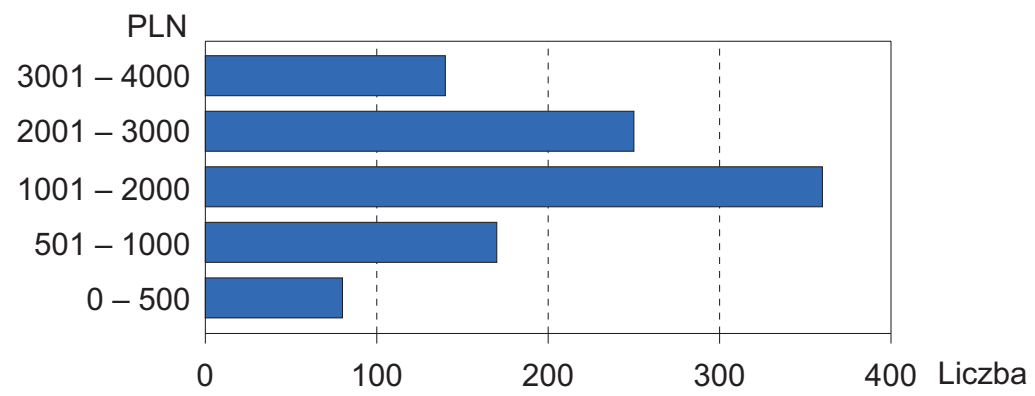

Wykres 1. Dochód na członka rodziny respondenta (w zł)

Źródło: wyniki badań własnych.

Celem analizy ekonomicznej było także ustalenie, jak kształtują się ceny produktów zdrowej i ekologicznej żywności w opinii badanych. Zdaniem większości respondentów $(74,5 \%)$ ceny produktów zdrowych są wysokie i dość wysokie (znacznie wyższe niż produktów tradycyjnych). Dla pozostałych $20,5 \%$ badanych ceny są przystępne (na średnim i przeciętnym poziomie). Tylko 5\% respondentów uważa, że są one niskie. 


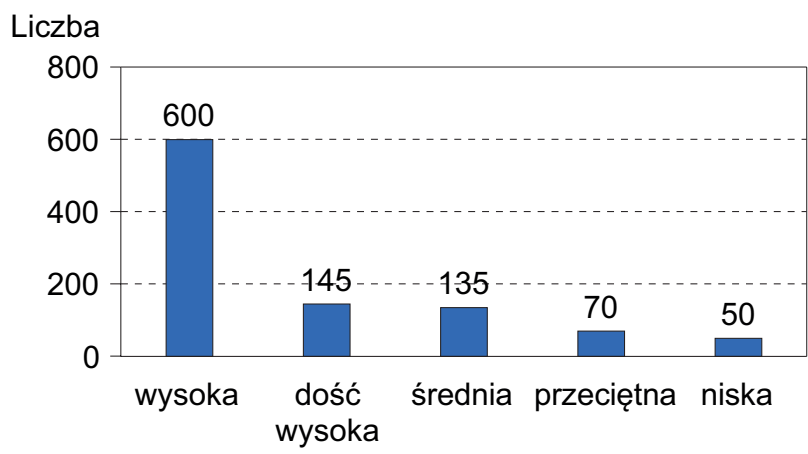

Wykres 2. Wysokość cen produktów ekologicznych zdaniem respondentów

Źródło: wyniki badań własnych.

\section{Analiza socjologiczna}

W celu dokładnego sprawdzenia zdrowego stylu życia młodych konsumentów należy dokonać także analizy socjologicznej. Jak wynika z części teoretycznej, jednym z głównych składników zdrowego stylu życia jest spożywanie zdrowej i ekologicznej żywności oraz uprawianie sportu. Wykorzystując posiadaną wiedzę, poproszono badanych, aby wskazali, czy spożywają zdrowe jedzenie. Zdecydowana większość (89\%) odpowiedziała „tak”, pozostali badani $(11,0 \%)$ nie konsumują tego typu produktów, choć wśród tej części badanych $10 \%$ deklaruje, że okazjonalnie spożywa tego typu produkty (na przykład jako poczęstunek u znajomych).

Głównym powodem zakupu zdrowej żywności przez respondentów jest dbanie o dobre samopoczucie i oczyszczenie organizmu (48\%). Nieco mniej badanych nabywa ekologiczną żywność z powodu chęci zmiany nawyków żywieniowych $(22,5 \%)$. Co dziesiąty badany kupuje tego typu produkty ze względu na modę (10\%). Pozostali badani $(6,0 \%)$ wskazali na chęć poprawy zdrowia i uzupełnienia leczenia, ze względu na brak składników GMO w tego typu produktach.

\section{Cząstkowa ocena zdrowego stylu życia}

Ocena została przeprowadzona w pięciopunktowej skali Likerta. W ocenie cząstkowej uwzględniono następujące aspekty zdrowego stylu życia: konsumowanie zdrowych i ekologicznych produktów, rodzaj kupowanej zdrowej żywności, liczba członków rodziny kupujących zdrowe i ekologiczne produkty, miejsce dokonywania takich zakupów oraz aktywność fizyczna.

Wśród wszystkich badanych zdecydowana większość (89\%) odpowiedziała, że nabywa zdrową żywość, a tylko $11 \%$ ankietowanych uważa, że nie stać ich na to. W związku z tym zapytano respondentów, czy konsumują zdrową żywność, kto w gospodarstwie domowym dokonuje zakupów produktów „eko”/,bio” i czy 
prowadzą aktywny tryb życia. W odpowiedzi na drugie pytanie najczęściej wskazywali na siebie (35,5\%), nieco mniej osób - na partnera (24\%), a w opinii $21,7 \%$ badanych żywność ekologiczną kupują rodzice; pozostali badani $(7,8 \%)$ uważają, że zakupu zdrowej żywności dokonują na przemian z partnerem (wykres 3).

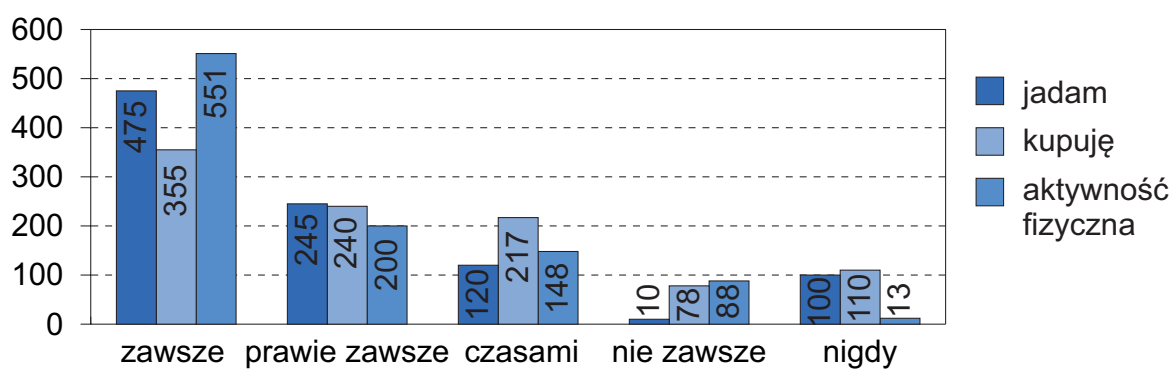

Wykres 3. Zakup i konsumpcja produktów ekologicznych przez respondentów oraz aktywność fizyczna

Źródło: wyniki badań własnych.

Równie interesującym zjawiskiem jest poznanie kategorii najczęściej nabywanych produktów zdrowej i ekologicznej żywności. Na rynku zdrowej i ekologicznej żywności dostępna jest zróżnicowana oferta tego typu żywności, w związku z czym nasuwa się pytanie o najczęściej kupowane produkty. Jak pokazują badania, respondenci kupują kilka produktów, wśród których są: surowe mięso $(88,7 \%)$ i wędliny $(86,9 \%)$ (chodzi mięso i wędliny kupowane bezpośrednio od rolnika sprzedającego wyroby z własnego uboju we własnym sklepie i w małych sklepach mięsnych). W dalszej kolejności badani wskazali na: pieczywo $(85,6 \%)$, jajka $(78,5 \%)$ i wafle ryżowe $(75,4 \%)$; owoce kupuje $62,4 \%$, warzywa $-58,8 \%$, ryż - 48,8\%, napoje - 45\%. Z kolei najmniejszy procent badanych dokonuje zakupu zdrowych/ekologicznych słodyczy - 11,5\%, różnego rodzaju mąk 9,8\%, kasz - 7,3\% i jogurtów - 7,2\%.

Zgromadzony materiał badawczy pozwolił także ustalić, gdzie badani najczęściej dokonują zakupu zdrowej i ekologicznej żywności. Jest to jeden z kluczowych aspektów prowadzonego badania, ponieważ wskazuje na preferencje ankietowanych, które mogą być warunkowane dochodem. 43,8\% ankietowanych dokonuje zakupów w sklepach stacjonarnych, a 39,3\% kupuje zdrową i ekologiczną żywność na osiedlowych bazarach i targowiskach. Sporo badanych wskazało również na sklepy ekologiczne $(7,9 \%)$. Wzrasta też nabywanie produktów przez Internet (9\%), przede wszystkim ze względu na możliwość kupienia żywności w niższej cenie (bez marży sklepowej). 


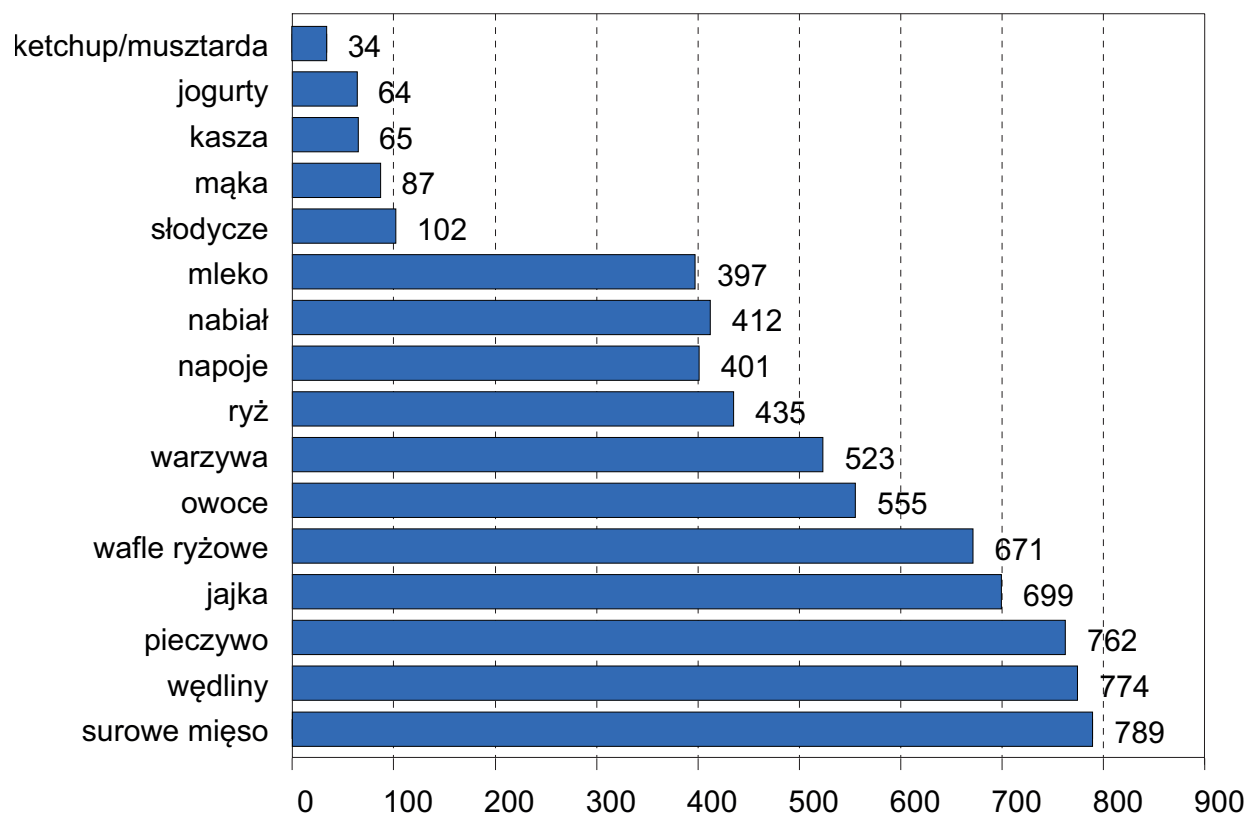

Wykres 4. Artykuły zdrowej i ekologicznej żywności nabywane przez respondentów

Źródło: wyniki badań własnych.

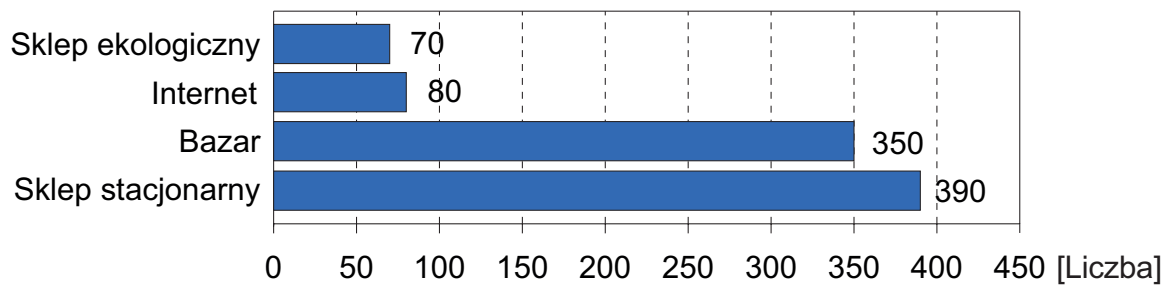

Wykres 5. Miejsce zakupu zdrowej i ekologicznej żywności

Źródło: wyniki badań własnych.

Zdaniem zdecydowanej większości badanych (75\%) dochód nie warunkuje kupna karnetu i korzystania z klubów sportowych. Wśród tej grupy znalazły się głównie osoby pracujące i studenci, którzy mogą korzystać między innymi ze zniżki wynikającej z posiadania aktualnej legitymacji studenckiej. W wielu klubach sportowych oferowane są bowiem niższe karnety zachęcające studentów do aktywności. Podobnie wygląda sytuacja na basenach rekreacyjnych czy innych miejscach sportowo-rekreacyjnych, pozwalających zadbać o sylwetkę. Jak wynika z badań, $25 \%$ respondentów uważa, że poziom dochodu ma wpływ na korzystanie z klubów fitness i siłowni. Najczęściej taką odpowiedź wskazywały osoby niepracujące i po- 
zostające na utrzymaniu rodziców, przez których zakup karnetu może być potraktowany jako potrzeba niższego rzędu, której nie są w stanie zaspokoić.

Sport to szeroko rozumiana aktywność fizyczna. Wiele osób uprawia ćwiczenia na świeżym powietrzu (bieganie, gimnastyka, jazda na rowerze). Zapytano zatem badanych, jaką aktywność fizyczną wybierają najczęściej. Większość respondentów $(65,1 \%)$ najczęściej wybiera bieganie i jazdę na rowerze, tylko nieliczni wskazali na uprawianie nordic walkingu (13,3\%), pływanie (12,3\%), sztuki walki $(6,5 \%)$ oraz jogę $(2,8 \%)$.

\section{Wnioski}

Młode osoby to ważna grupa konsumencka ze względu na kształtowanie prawidłowych nawyków zdrowotnych oraz przekazywanie wiedzy w tym zakresie. Narastający trend prowadzenia zdrowego stylu życia determinuje także zachowania producentów, przez co coraz powszechniejsza (a zarazem tańsza) staje się oferta zdrowych i ekologicznych artykułów spożywczych. Wzrasta również liczba sklepów oferujących szeroką gamę zdrowych produktów. Ma to także związek ze zrównoważoną konsumpcją, którą uznaje się za stałą zmianę w zachowaniach konsumenckich młodych konsumentów, a nie chwilową modę.

Wśród młodych konsumentów wzrasta zainteresowanie zdrową i ekologiczną żywnością oraz aktywnością sportową, co wpływa też na zwiększony popyt na te produkty i usługi na rynku. W tej kwestii dostrzega się, że z roku na rok rośnie liczba osób uprawiających sport.

Według Raportu Ośrodka Ewaluacji wysoka cena produktów ekologicznych jest dla $73 \%$ badanych największą przeszkodą. Według Chudzika badani deklarują chęć nabywania zdrowych produktów, jednak kiedy kupują produkty, w największym stopniu kierują się ceną $(75 \%)$. Potwierdzają to inne badania, w tym przedstawione w tym tekście — zdaniem większości respondentów (74,5\%) ceny produktów zdrowych są wysokie.

Badania przeprowadzone na potrzeby artykułu obejmowały próbę badawczą młodych konsumentów w wieku 20-35 lat. Wybrana próbka stanowiła grupę reprezentatywną (na przyjętym poziomie istotności) pod względem wieku.

Dokonana analiza ekonomiczno-socjologiczna wskazuje, że młodzi konsumenci to osoby mające pełną świadomość znaczenia zdrowej żywności i aktywności fizycznej w codziennym życiu. Natomiast badania przeprowadzone przez agencję badawczą MANDS w 2019 roku pokazują, że 40\% Polaków deklaruje kupowanie produktów zdrowej i ekologicznej żywności. Nasze badania dowodzą, że młodzi konsumenci (89\%) z województwa dolnośląskiego kupują zdrową żywność. Większość z nich dostrzega zalety nabywania zdrowych produktów żywnościowych. Dlatego młodzi konsumenci starają się nabywać zdrową żywność po niższej cenie, co umożliwia im wykonywanie zakupów w marketach 
i Internecie. Największym zainteresowaniem cieszy się zakup surowego mięsa, pieczywa oraz jajek, a zatem produktów podstawowych. Jednocześnie ci sami respondenci podkreślą istotę bycia aktywnym ruchowo. Dominującymi aktywnościami są bieganie i jazda na rowerze. Uczęszczanie do klubów sportowych i fitness wciąż należy do mniejszości, choć i w tej kwestii dostrzega się rosnący udział badanych. $Z$ analizy materiału empirycznego wynika jednak, że aktywność fizyczna młodych konsumentów nie jest zdeterminowana przez uzyskiwany przez nich dochód. Jest to optymistyczny aspekt badań, który wskazuje na wysoki poziom świadomości prozdrowotnej osób w wieku 20-35 lat.

Respondenci uważają także, że oprócz samego jedzenia zdrowej żywności potrzebny jest aktywny tryb życia, który w przeciwieństwie do zakupu zdrowej żywności nie generuje tak wysokich kosztów.

$\mathrm{Na}$ podstawie przeprowadzonych badań można wysunąć następujące wnioski:

1. Osoby w wieku 20-35 lat zdają sobie sprawę, że w utrzymaniu zdrowia i formy konieczne jest kompleksowe działanie, a więc nie tylko nabywanie zdrowych produktów, lecz także kształtowanie zdrowych nawyków żywieniowych.

2. Zakup zdrowej i ekologicznej żywności przez młodych konsumentów wynika przede wszystkim z posiadanej wiedzy i świadomości prozdrowotnej. Młodzi konsumenci zdają sobie sprawę, że ekologiczna żywność jest zdrowsza, a poprzez nabywanie tańszych produktów, na przykład bezpośrednio u rolnika lub za pośrednictwem sklepów internetowych, możliwe jest utrzymanie zdrowego stylu życia.

3. Zdrowy styl życia determinowany jest również aktywnością fizyczną. Badania własne dowodzą, że młodzi konsumenci są świadomi tego, że w utrzymaniu zdrowia ważna jest systematyczna aktywność fizyczna. Uczęszczanie do klubów sportowych jest jedną z wielu opcji, która jednak w opinii badanych nie jest tą najczęściej wybieraną. Chętniej decydują się na jazdę na rowerze bądź bieganie, co pozwala podtrzymać wniosek, iż wysokość dochodów młodych konsumentów nie wpływa znacząco na poziom ich aktywności fizycznej.

\section{Bibliografia}

Antonides, G., Fred, van Raji W. (2013). Zachowanie konsumenta. Warszawa: PWN.

Blalock, H.M. (1975). Statystyka dla socjologów. Warszawa: PWN.

Bożewicz, M. (2019). Jak zdrowo odżywiają się Polacy?, komunikat z badań nr 106/2019. Warszawa: CBOS.

Chudzik, K. (14.01.2015). Polacy coraz częściej kupują ekologiczną żywność. Popyt rośnie w tempie ok. 20 proc. rocznie. Wirtualna Polska. Data dostępu: 21.02.2020, https://finanse.wp.pl/ polacy-coraz-czesciej-kupuja-ekologiczna-zywnosc-popyt-rosnie-w-tempie-ok-20-proc-rocznie-6114760433653377a. 
Dziewanowska, K., Kacprzak, A. (2013). Ekologiczna konsumpcja na pokaz. Analiza społecznych i marketingowych skutków kreowania „Eko-ikon”. Zeszyty Naukowe Uniwersytetu Szczecińskiego. Problemy Zarządzania, Finansów i Marketingu, 32, 39-53.

GUS. (2019). Rocznik Demograficzny. Warszawa.

Hellwig, Z. (1993). Elementy rachunku prawdopodobieństwa i statystyki matematycznej. Warszawa: PWN.

Hermaniuk, T. (2018). Postawy i zachowania konsumentów na rynku ekologicznych produktów żywnościowych. Handel Wewnętrzny, 2, 189-199.

Krupa, J., Drobnica, L. (2009). Preliminary estimate of food preferences among college students. W L. Wdowiak, W. Kruk, M. Binkowska-Bury (red.), Public Health and Research. Lublin: Wydawnictwo NeuroCentrum.

Leszczyńska, M., Pogoda, I., Szostakowska, M., Ulanicka, M. (2015). Raport: Kogo nęci zdrowe jedzenie?. Warszawa: Ośrodek Ewaluacji OE.

Mańkowska-Wróbel, L. (2014). Ekologiczne uwarunkowania zachowań konsumenckich. Handel Wewnetrzny, 1, 141-150.

Moczulski, M. (2018). Żywność z rekordem i lękiem o przyszłość. Rzeczpospolita. Data dostępu: 1.11.2020, z:https://www.rp.pl/Wywiady/309159903-Marek-Moczulski-Zywnosc-z-rekordem-ile kiem-o-przyszlosc.html.

Ostrowska, A. (1999). Style życia a zdrowie z zagadnień z promocji zdrowia. Warszawa: Wydawnictwo IFiS PAN.

Poskrobko, B. (2007). Zarzadzanie środowiskiem. Warszawa: Wydawnictwo PWE.

Rogo, B. (2016). Styl życia studentek a ich przekonania zdrowotne i preferowane wartości. W A. Kaźmierczak (red.), Pedagogiczny wymiar kultury fizycznej i zdrowotnej w życiu wspótczesnego człowieka. Łódź: Wydawnictwo UŁ.

Rudnicki, L. (2000). Zachowania konsumentów na rynku. Warszawa: Wydawnictwo PWE.

Solomon, R. (2006). Zachowania i zwyczaje konsumentów. Gliwice: Wydawnictwo Helion.

Sowa, I. (2016). Wykorzystanie koncepcji stylu życia w typologii młodych konsumentów. Studia Ekonomiczne. Zeszyty Naukowe Uniwersytetu Ekonomicznego w Katowicach, 303, 134-151.

Tyszka, A. (1971). Uczestnictwo w kulturze. Warszawa: PWN.

Zalega, T. (2012). Konsumpcja. Determinanty, teorie, modele. Warszawa: Wydawnictwo PWE.

Ekonomia - Wroclaw Economic Review 26/4, 2020

(C) for this edition by CNS 